\title{
Original article (short paper) \\ Long distance run induced hydration and kidney function changes in marathoners
}

\author{
Luiz Guilherme Cruz Gonçalves \\ Rodrigo Leal de Queiroz Thomaz de Aquino \\ Enrico Fuini Puggina \\ Universidade de São Paulo, Ribeirão Preto, SP, Brazil
}

\begin{abstract}
The aim of the study was to verify the hydration status and the kidney function in marathoners during the training season and after a marathon race. Nine male runners were investigated during 12 weeks of training. Urine was collected in four moments; in the beginning $(\mathrm{C} 1)$ and during $(\mathrm{C} 2)$ the training program, before $(\mathrm{C} 3)$ and after $(\mathrm{C} 4)$ the competition. Urine $\mathrm{pH}$ was measured using reagent tapes, urine density with a refractometer, protein excretion by Bradford assay and erythrocytes and leucocytes by microscopy. Changes were observed when C-4 was compared to the other collection times for all variables investigated. It is possible to conclude that physical exertion induced important changes in the hydration status and glomerular membrane selectivity to macromolecules, modifying the kidney function of the marathoners in $\mathrm{C} 4$.
\end{abstract}

Keywords: marathon, dehydration, kidney function, urine analysis

Resumo - “Corrida de longa distância induz a mudanças no estado de hidratação e na função renal em maratonistas." O objetivo do estudo foi verificar o estado de hidratação e a função renal de maratonistas durante uma temporada preparatória e após a competição. Foram estudados nove maratonistas durante 12 semanas de treinamento. A urina foi coletada em quatro momentos: antes $(\mathrm{C} 1)$ e durante $(\mathrm{C} 2)$ o protocolo de treinamento, antes $(\mathrm{C} 3)$ e após (C4) a competição. Foram mensurados o pH a partir de tiras de reagentes, a densidade por meio do refratômetro, a proteinúria pelo ensaio de Bradford, concentração de eritrócitos e de leucócitos por microscopia. Alterações foram encontradas quando comparado o C-4 com as coletas anteriores para todas as variáveis estudadas. Pode-se concluir que o exercício físico induziu a modificações importantes no estado de hidratação dos corredores e na função da membrana glomerular, modificando assim, a função renal dos maratonistas no momento pós prova.

Palavras-chave: maratona, desidratação, função renal, análises urinárias

Resumen - "Funcionamiento para un cambios de larga distancia inducido en el estado de hidratación y función renal en maratonistas." El objetivo del estudio fue determinar el estado de hidratación y la función renal en los corredores de maratón durante una temporada de preparación y después de la competición. Se estudiaron nueve corredores durante 12 semanas de entrenamiento. La orina se recogió en cuatro momentos: antes y durante el protocolo de entrenamiento, antes y después de la competición. PH de tiras reactivas, de densidad a través del refractómetro, proteinuria por Bradford ensayo, concentración de eritrocitos y leucocitos fueron medidos por microscopía. No se encontraron cambios al comparar el C-4 con las colecciones anteriores para todas las variables. Se puede concluir que el ejercicio induce cambios significativos en el estado de hidratación de los corredores y la función de la membrana glomerular, modificando de este modo la función renal del tiempo de maratón después de la carrera.

Palabras claves: maratón, deshidratación, la función renal, análisis urinario

\section{Introduction}

Despite the apparent security in participating in a marathon or other similar sport, it is necessary to draw attention to possible physical occurrences during the exercise practice (Holtzhausen et al., 1994; Roberts, 2000). These abnormalities may be caused by one factor or by a combination which include hyponatremia, hipoglycemia, hypothermia, hyperthemia, dehydration and even cardiac arrest. The primary cause of these physical events is the hypertension produced by exertion during the race, causing dehydration and/or coronary misfit, leading to the interruption of the exercise (Robert, Kenefick, \& Sawka, 2007).

Due to the long distance exertion such as during endurance races, it is possible to detect excretion of blood cells and proteins in the urine caused by acute changes in the kidney function, mainly in respect to the glomerular permeability induced by the total blood flow reduction in the kidney. The main cause associated with this event is the catecholamine release, causing the constriction of blood vessels and consequently reducing the glomerular filtration 
ratio. Once exercise induced dehydration is installed, the filtration ratio may be even more reduced (Clerico et al., 1990).

However, dehydration mainly depends on the hydric balance of the body and is caused by many factors. The renin-angiotensyn-aldosteron-axis regulates the sodium retention and the vasopressin (anti diuretic hormone) regulates the water absorption in the kidney. The vasopressin also participates in the thermoregulation in the hypohydration in athletes. Additionally, the atrial natriuretic peptide secreted by the heart also participates in the water balance in the body. Therefore, the hydration status of an athlete during the exertion is regulated by many factors and hormones (Von Duvillard, Braun, Markofski, Beneke, \& Leithäuser, 2004).

Analyses of biochemical markers in the urine measure possible changes in the body composition and quantify the loss of individual sweat, and are very reliable ways to determine the acute changes that may indicate dehydration. The effects of dehydration are known to impair the cognitive system (Grandjean \& Grandjean, 2007), increase of the heat illness and by the reduction of aerobic performance in amateur athletes, mainly when the training program in conduced in extremely hot environmental conditions (ACSM et al., 2007; Casa et al., 2000).

Furthermore, athletes competing alone and away from any support are the most critical situations that can cause dehydration or even potential negative effects of this condition (O'Neal et al., 2011). Therefore, Dion, Savoie, Asselin, Gariepy, and Goulet (2013) suggested hydration guidelines to help long distance athletes in competitive moments. Changes in biochemical markers in the urine such as $\mathrm{pH}$, density, protein excretion and the elimination of blood cells through urine represent possible indicators which may help to clarify these issues.

One of the most studied variables is the red blood cells excretion, called hematuria, characterized as a frequent acute effect of long distance running. The abnormal presence of erythrocytes in urine may indicate kidney inflammation, infection or trauma or in the urinary tract, and also indicates neoplasic diseases in the urogenital tract. However, in these cases, the renal and urogenital abnormalities tend to disappear in those who practice regular physical activity (Bellinghieri, Savica, \& Santoro, 2008; Puggina, Machado, Tourinho Filho, $\&$ Barbanti, 2014). The most likely explanation for the appearance of hematuria is the mechanical breakdown of red blood cells through the trauma that occurs when the runner contacts the ground at the initial foot contact and when the toe clears off the stance phase during running (O'Toole, Hiller, Roalstad, \& Douglas, 1988). However, hematuria appears to be attenuated in athletes when they are compared to amateur competitors and tends to disappear after few hours of recovery. Moreover, the hematuria seems to be more sensitive to environmental variables such as heat, than to other factors such intensity of the exertion (Puggina, Machado, Borges, \& Barbanti, 2011).

Proteinuria can be also found in urine as a consequence of exercise, dehydration or stress (Abuelo, 1983; Reuben, Wachtel, Brown, \& Driscoll, 1982). The increase of protein excretion brings hemodynamic modifications in the kidney, specifically at the glomerular level, which is induced by vasoactive mediators and combined with partial tubular inhibition to macromolecules associated with the electrolytes excretion (Poortmans, 1984).

As in hematuria, the occurrence of protein excretion is highly dependent of variables as load and intensity of the training or the exertion, i.e., it seems that more intense exercise may lead to more prominent proteinuria. However, few hours after the competitions, the proteins level in urine tends to return to the physiological level (Gerth et al., 2002; Miyai \& Ogata, 1990; Edes, Shah, \& Thornton, 1990).

Due to the increasing interest of the population in events of long distance races in the last decade, especially in outdoor races, we need to understand the effects of a training season for a long distance running as well the race itself in the hydration status and in the kidney function of amateur athletes aiming to understand the dynamic of variation of these indicators in runners. Additionally, to investigate the particularity of a marathon race does not imply to extend results of this type of analysis to other aerobic sport modalities as an ironman, half ironman, half marathon, $10 \mathrm{~km}$ races, road cycling, mountain bike and others (Mydlík, Derzsiová, \& Bohus, 2009).

In this sense, we believe that is very important to measure and evaluate the effects of long term exertion in conditions of training and competition, providing knowledge to the coaches about the effects of high levels of exertion and allowing the adoption of strategies in order to avoid negative effects (Moreira, Okano, De Souza, Oliveira, \& Gomes, 2005).

In this sense, the aim of this study was to verify the possible changes in the hydration status (urine $\mathrm{pH}$ and density) and in the kidney function (excretion of erythrocytes, leucocytes and protein) during the training season, as well before and after the target competition in amateur marathoners.

\section{Methods}

\section{Participants}

Nine male marathoners volunteered to participate in the study. The sample characteristics are expressed in the Table 1.

This study was approved by the Ethics Committee of the School of Pharmaceutical Sciences of Ribeirão Preto, registered as $n^{\circ} 168$. All the participants signed the informed consent informing the objectives and methods of this study.

Table 1. Characterization of the study sample.

\begin{tabular}{cc}
\hline Variables & Mean \pm standard deviation \\
\hline $\mathrm{N}$ & 9 \\
Age (years) & $34.78 \pm 10.62$ \\
Gender & Male \\
Height $(\mathrm{cm})$ & $170.15 \pm 8.06$ \\
Body weight $(\mathrm{kg})$ & $70.54 \pm 7.88$ \\
IMC $(\mathrm{kg} / \mathrm{m} 2)$ & $24.41 \pm 2.23$ \\
\% of fat & $13.83 \pm 5.51$ \\
Training experience (years) & 2 \\
\hline
\end{tabular}




\section{Training protocol}

The athletes were submitted to a twelve week training protocol composed by $80 \%$ of aerobic continuous training in the average intensity of the lactate threshold and $20 \%$ of interval training aiming to participate in the São Paulo marathon. Training intensity was obtained and monitored using the heart rate in the mentioned intensities.

\section{Urine collection and analysis}

Urine was collected four hours after the last void in four instances: in the beginning of the training program (C-1), end of the extensive training and beginning of the intensive training (C-2), 24 hours before the competition (C-3) and 30 minutes after the marathon $(\mathrm{C}-4)$. The urine collection was carried after the asepsis of the genital organ and the samples stored between 2 to $8^{\circ} \mathrm{C}$ and transported to the laboratory for further analysis.

The urinary $\mathrm{pH}$ was determined using reagent tapes Urofita 10DL, from Biobrás Diagnósticos ${ }^{\circledR}$, Belo Horizonte, Brazil. Urine density was measured using a manual refractometer Uricon $\mathrm{N}$ from Atago ${ }^{\circledR}$, Tóquio, Japan. The optical density was measured for each sample using a spectrophotometer Ultrospec 3100 Pro, from Amersham Pharmacia Biotech ${ }^{\circledR}$, Piscataway, USA. Additionally, the cell counts (erythrocytes and leucocytes) were carried in the urinary sediment using hemocytometer and a microscope.

Finally, the protein content was obtained with the method proposed by Bradford (Bradford, 1976). The total protein content was obtained through a calibration curve multiplied by the dilution factor and expressed in $\mathrm{mg} / \mathrm{dL}$.

\section{Data analysis}

Results were treated using the GraphPad and Prism ${ }^{\circledR}$ statistical packages (La Jolla, GraphPad Software, USA). The normal distribution of the data was verified with the Shapiro-Wilk test and the repeated measurements ANOVA was used to detect possible differences. When necessary, the Bonferroni post-hoc test was performed to determine differences between the collection times. The significance level adopted was $p<.05$.

\section{Results}

Figure1 displays the results obtained for urine $\mathrm{pH}$ (A) and urine density (B). For the urine $\mathrm{pH}$ was found $5.18 \pm$ $0.2 \mathrm{U} / \mathrm{A}$ in $\mathrm{C}-4$, evidencing a significant reduction $(p \leq .05)$ when this result was compared to $\mathrm{C}-1: 6.5 \pm 0.46 \mathrm{U} / \mathrm{A}$; $\mathrm{C}-2$ : $6.56 \pm 0.49 \mathrm{U} / \mathrm{A}$ and $\mathrm{C}-3: 6.43 \pm 0.41 \mathrm{U} / \mathrm{A}$. Concerning about the urine density, in $\mathrm{C} 4$ was found $1030.62 \pm 1.76 \mathrm{U} / \mathrm{A}$, a significant increase $(p \leq .05)$ when comparisons were made with C-1: $1011.8 \pm 2.58 \mathrm{U} / \mathrm{A} ; \mathrm{C}-2: 1011.85 \pm 2.54 \mathrm{U} / \mathrm{A}$ and C-3: $1011 \pm 2.56 \mathrm{U} / \mathrm{A}$. Summarizing, in both cases were found differences after the marathon when comparing this moment with earlier collections, evidencing the dehydration produced by the competition in relation to the training protocol measurements.
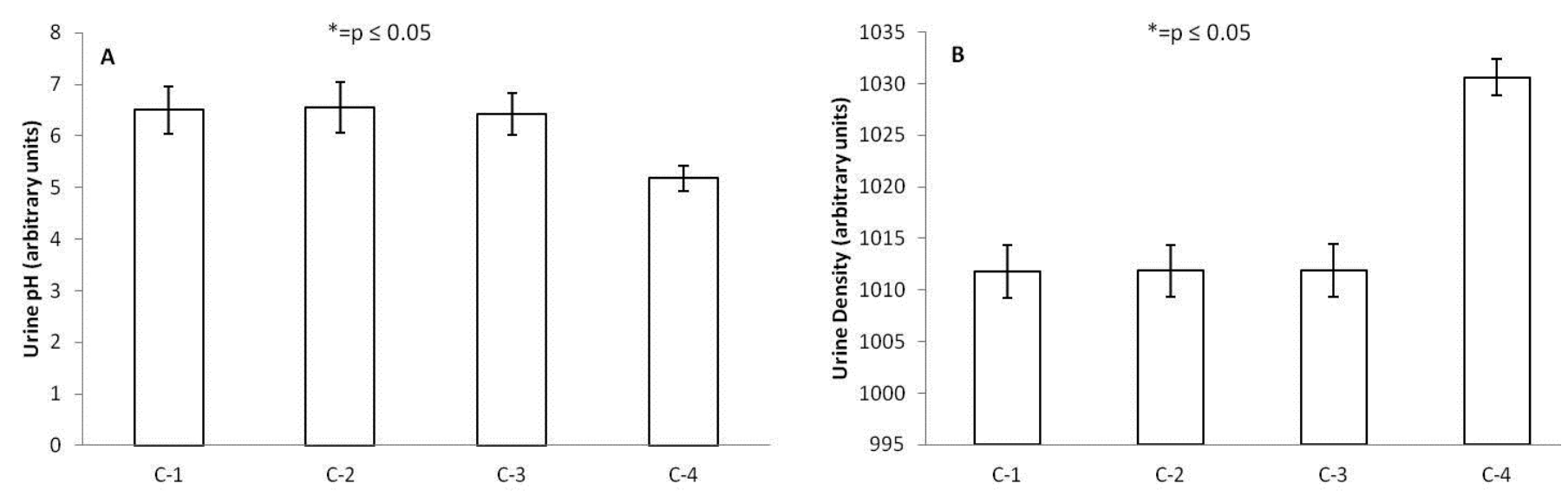

Figure 1. Urine $\mathrm{pH}$ in arbitrary units $(1 \mathrm{~A})$ and urine density in arbitrary units $(1 \mathrm{~B})$ before $(\mathrm{C}-1)$, during the training program $(\mathrm{C}-2)$, before $(\mathrm{C}-3)$ and after the competition (C-4). $*=p<.05$.

For the erythrocytes (Figure 2A), the increase found in $\mathrm{C} 4$ was approximately $4000 \%(56665 \pm 421.42 \mathrm{U} / \mathrm{mL})$ compared to the other collection times $(\mathrm{C} 1: 1150 \pm 350.51 \mathrm{U} / \mathrm{mL} ; \mathrm{C} 2$ : $1087.50 \pm 180.77 \mathrm{U} / \mathrm{mL}$ and $\mathrm{C}-3: 1275 \pm 452.77 \mathrm{U} / \mathrm{mL})$. The leukocytes count revealed (Figure $2 \mathrm{~B}$ ) the $300 \%$ increase in $\mathrm{C} 4(6437.50 \pm 4065.90 \mathrm{U} / \mathrm{mL})$ in the comparisons performed with the earlier collections (C-1: $2087.50 \pm 180.77 \mathrm{U} / \mathrm{mL} ; \mathrm{C}-2$ :
$2150 \pm 226.78 \mathrm{U} / \mathrm{mL}$ and C-3: $2137.50 \pm 189.55 \mathrm{U} / \mathrm{mL})$. Taken together, the results shown in figure 2 revealed the acute changes in the kidney function after the marathon, illustrating the effects of this level of exertion in the investigated indicators.

Similarly to the data found for leukocytes and erythrocytes, the protein excretion revealed an increase after the competition (Figure 3 ). In the experiments performed to 
detect the protein excretion in urine, in C4 was found 30.82 $\pm 12.59 \mathrm{mg} / \mathrm{dL}$, an increase of $400 \%(p \leq .05)$ compared to

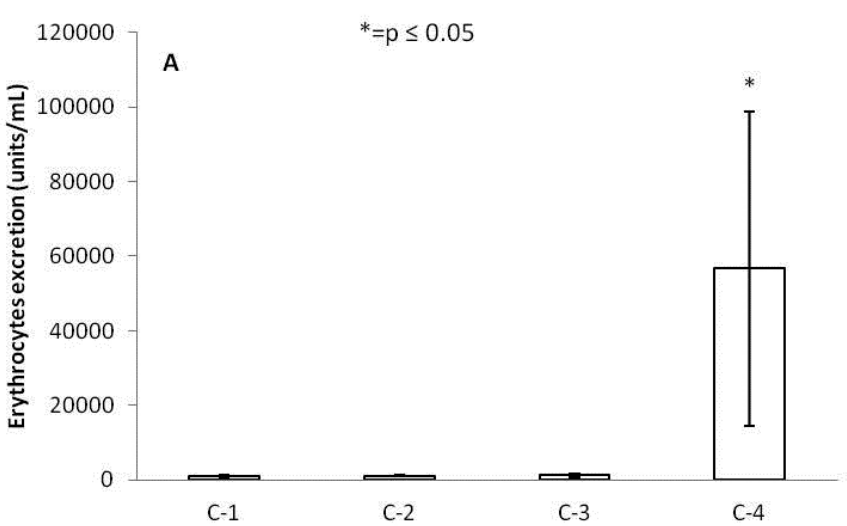

the other three collection times $(\mathrm{C}-1: 5,10 \pm 2.38 \mathrm{mg} / \mathrm{dL} ; \mathrm{C}-2$ : $7.93 \pm 1.88 \mathrm{mg} / \mathrm{dL}$ and $\mathrm{C}-3: 6.56 \pm 2.42 \mathrm{mg} / \mathrm{dL})$.

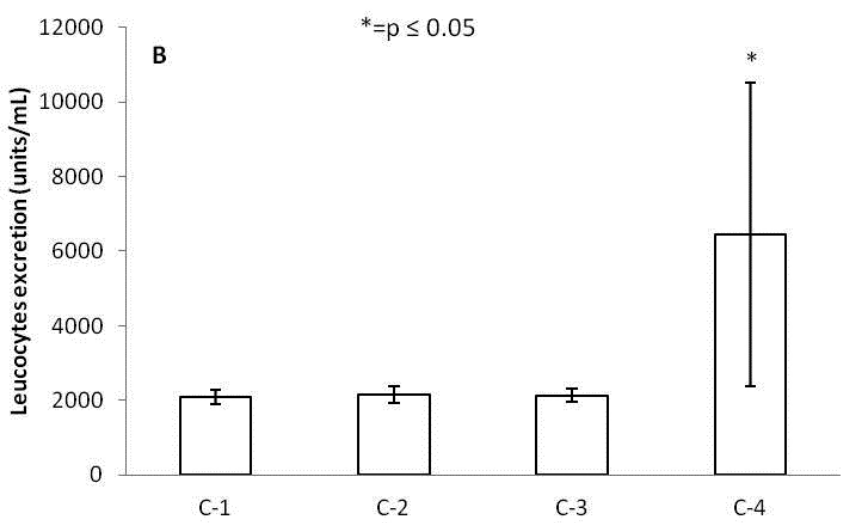

Figure 2. Erythrocytes count in units/mL (1A) and leucocytes count in units/mL (1B) before (C-1), during the training program $(\mathrm{C}-2)$, before (C-3) and after the competition (C-4). ${ }^{*}=p<.05$.

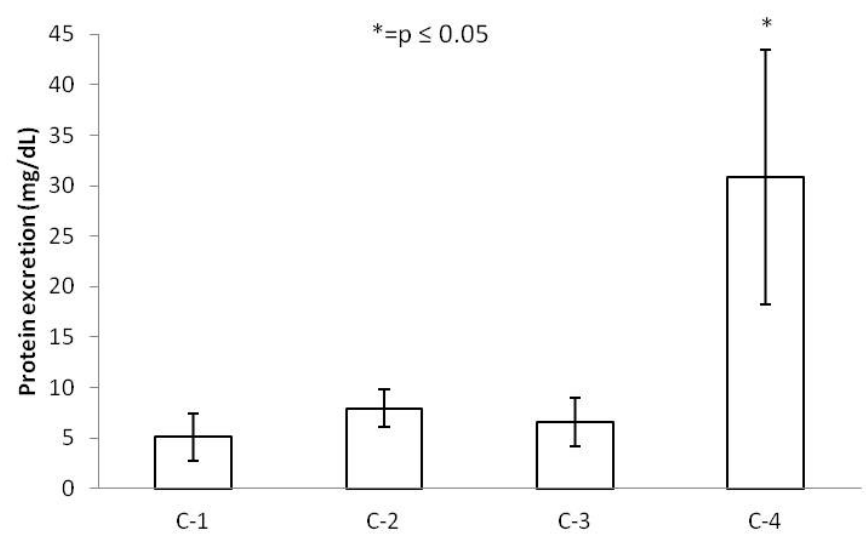

Figure 3. Protein excretion in $\mathrm{mg} / \mathrm{dL}$ before $(\mathrm{C}-1)$, during the training program $(\mathrm{C}-2)$, before $(\mathrm{C}-3)$ and after the competition $(\mathrm{C}-4)$. $*=p<.05$.

\section{Discussion}

The main findings of this study was the significant changes in the hydration status (urinary $\mathrm{pH}$ and urine density) and in the kidney function (erythrocytes, leucocytes and protein excretion) 30 minutes after the marathon when compared to the other collection times $(\mathrm{C} 1, \mathrm{C} 2$ and $\mathrm{C} 3)$.

Regarding the data acquired for urine $\mathrm{pH}$ and density, Clerico et al. (1990) verified changes at the glomerular level, specifically in the permeability to the macromolecules, meaning that taken together, urine $\mathrm{pH}$ and density indicate that the exercise load induced the athletes to the dehydration state after the competition. This fact may be explained due to the signaling cascade triggered though the central nervous system to release catecholamine (not verified in this study), reducing the glomerular blood flow and resulting in the reduction of the glomerular filtration ratio. These physiological effects revealed the dehydration and resulted in the excretion of metabolites acutely produced during the competition, similarly to the finding of Mydlík, Derzsiová, and Bohus (2012) in runners that participated in a $16 \mathrm{~km}$ competition and revealed signs of dehydration after exertion. Also similarly to this study, in the Mueller, Anliker, Knechtle, Knechtle, and Toigo (2013) study with triathletes, changes in body composition and decrements in the water content were found after an ironman triathlon.

The erythrocytes excretion in urine was significantly increased after competition, illustrating that possibly the changes in the glomerular permeability are due to exertion, as well as the renal tract damage that probably were produced by the mechanical forces during the run. I this sense, it may be considered that high intensity exertion could result in hematuria, since it is a known effect of long distance sports and is believed, considered a frequent and benign effects started in the kidney and bladder due to the increased blood flow induced by the exercise. From these findings, Le Meur, Paraf, Szelag, Aldigier, and Leroux-Robert (1998) suggests that the main cause of the acute kidney failure is the hematuria originated at the glomerular level probably due to the intraluminal obstruction triggered by the exercise. 
On the other hand, there is a toxic effect of hemoglobin in the tubular cells, described as a mechanism responsible by the acute kidney failure in the IgA nephropathy cases with glomerular bleeding (Fogazzi et al., 1995). Despite the clinical condition installed after the strenuous exertion, the exercise effect is transient and is not associated with any pathology (Bellinghieri et al., 2008; Irving, Noakes, Irving, \& Van Zyl-Smit, 1986; Kallmeyer \& Miller 1993, Poortmans, 1984).

In relation to the leukocytes and erythrocytes, the results showed a significant increase in white and red blood cells content after the competition. In this sense, Poortmans (1984) suggests that during the exercise may occurs reductions of the kidney blood flow, kidney and urinary tract damage and glomerular filtration ratio reduction, leading to changes in the glomerular permeability.

The increase of the blood cells count in urine after long term exertion are being reported as a result of endocrine and kidney hemodynamic (blood pressure and blood flow) flow responses to the exercise (Poortmans, 1984). Adittionally, based on the functions of renin-angiotensin-aldosterone axis related to regulatory process of the hydration status, it is possible to infer that this system was activated due to the transitory functional abnormalities in the kidney after the marathon race. However, in this study, these variables were not measured directly, indicating the need to investigate these indicators during long term exercise.

The protein excretion increase after the competition in athletes may be in part confirmed by the recurrence of protein excretion in urine after physical exertion (Clerico et al., 1990), effect which was found in this study. On the other hand, the occurrence of exercise induced proteinuria is totally reversible when it is originated in the glomerlar tubules and membrane (Mydlík et al., 2012).

The prevalence of hematuria may be a result of functional variables, such as pregnancy, fever and physical exercise (Irving et al., 1986). In relation to the physiological aspect, proteinuria is predominantly composed by plasmatic proteins, being the albumin the most present. Therefore, this variable provides information about the hydration status of the subjects through the increment of the protein excretion at the end of the race, also indicating possible diminution of the liquid distribution in the kidney, as well glomerular changes since the glomerular permeability to macromolecules is limited by the molecular size and weight and by the electrostatic interactions between same circulating molecules and glomerular membrane components (Puggina et al., 2014), resulting in dehydration of the athletes.

Another possible mechanism for the non glomerular erythrocyturia after a race is the micro trauma in the urinary tract. The transitory reduction in the glomerular filtration ratio may be caused by the dehydration and by the reduction of blood flow caused by the effective plasmatic flux to the renal cortex (Mydlík et al., 2009).

Puggina et al. (2014) verified that physical exercise induced the increase of protein excretion after a half ironman triathlon, indicating that the main cause of this effect is related to albuminuria. However, the protein concentration in urine tends to return to the basal level after few hours rest
(Edes et al., 1990). In this way, the exercise induced proteinuria may be due to; dehydration, constriction of kidney blood vessels, reduced permeability of glomerular membrane, reabsorption of proteins in the renal tubules among other possible variables (Carroll \& Temte, 2000; Clarkson, 2007; Mydlík et al., 2012).

Therefore, from our results is possible to conclude that a long term exertion caused an acute changes in all variables studied (urine $\mathrm{pH}$, urine density, cell counts and proteinuria). Taken together, our results shows that long term exercise acutely affects kidney hemodynamic, as well impair the glomerular membrane permeability, resulting in abnormal kidney function (temporary) and dehydration in the marathoners.

Additionally, we can speculate about the endocrine variables such as ant diuretic hormone, catecholamine and aldosterone, leading to an increased activation of the renen-angiotensin-aldosteron axis. Thus, highlights the need for more studies concerning the endocrine parameters during a training season and during and after the endurance exercises.

Finally, the changes in hydration and kidney function found in the present study after the marathon were understood as a transient effect. In the field, coaches and athletes must pay attention in these symptoms that may appear as a consequence of training and competition, aiming to minimize the hazardous effects on function and physiology of the athletes.

\section{References}

Abuelo, J.G. (1983). Proteinuria: Diagnostic Principles and procedures. Annals of Internal Medicine, 98, 186-191.

Armstrong, L.E., Casa, D.J., Millard-Stafford, M., Moran, D.S., Pyne, S.W., \& Roberts, W.O. (2007). American College of Sports Medicine position stand: exertional heat illness during training and competition. Medicine \& Science in Sports \& Exercise, 39, 556-572.

Bellinghieri, G., Savica, V., \& Santoro, D. (2008). Renal Alterations during Exercise. Journal of Renal Nutrition, 18, 158-164.

Bradford, M. (1976). A rapid and sensitive method for the quantitation of microgram quantities of proteins utilizing the principle of protein dye binding. Analytical Biochemistry, 7, 248-254.

Carroll, M.F., \& Temte, J.L. (2000). Proteinuria in adults: A diagnostic aproach. American Family Physician, 62, 1333-1340.

Casa, D.J., Armstrong, L.E., Hillman, S.K., Montain, S.J., Reiff, RV., Rich, B.S.E., ...Stone, J.A. (2000). National Athletic Trainers'Association position statement: fluid replacement for athletes. Journal of Athletic Training, 35, 212-224.

Clarkson, P.M. (2007) Exertional rhabdomyolysis and acute renal failure in marathon runners. Sports Medicine, 37, 361-363.

Clerico, A., Glammatel, C., Cechinl, L., Lucheti, A., Cruscheil, L., Peno, G., ...Giampletro, G. (1990). Exercise-Induced Proteinuria in Welwwwl-Trained Athletes. Clinical Chemistry, 36, 562-564.

Dion, T., Savoie, F.A., Asselin, A., Gariepy, C., \& Goulet, E.D.B. (2013). Halfmarathon running performance is not improved by a rate of fluid intake above that dictated by thirst sensation in trained distance runners. European Journal of Applied Physiology, 113, 3011-3020. 
Edes, T., Shah, J., \& Thornton, J.R.W. (1990). Spontaneous Decline in Exercise-Induced Proteinuria During a 100-mile Triathlon. Southern Medical Journal, 83, 1044-1046.

Fogazzi, G.B., Imbasciati, E., Moroni, G., Scalia, A., Mihatsch, M. J., \& Ponticelli, C. (1995) Reversible acute renal failure from gross haematuria due to glomerulonephritis: not only in $\operatorname{IgA}$ nephropathy and not associated with intratubular obstruction. Nephorology Dialysis Transplantion, 10, 624-629.

Gerth, J., Ott, U., Fünfstück, R., Bartsch, R., Keil, E., Schubert, K., ...Stein, G. (2002). The Effects of Prolonged Physical Exercise on Renal Function, Electrolyte Balance and Muscle Cell Breakdown. Clinical Nephrology, 57, 425-431.

Grandjean, A.C., \& Grandjean, N.R. (2007) Dehydration and cognitive performance. Journal of the American College of Nutrition, 26, 549-554.

Holtzhausen, L.M., Noakes, T.D., Kroning, B., de Klerk, M., Roberts, M., \& Emsley, R. (1994) Clinical and biochemical charachteristics of collapsed ultramarathon runners. Medicine \& Science in Sports \& Exercise, 26, 1095-1101.

Irving, R., Noakes, T., Irving, G., \& Van Zyl-Smit, R. (1986). The immediate and delayed effects of marathon running on renal function. Journal of Urology, 136, 1176-1180.

Kallmeyer, J., \& Miller, N. (1993). Urinary Changes in Ultra LongDistance Marathon Runners. Nephron, 64, 119-121.

Le Meur, Y., Paraf, F., Szelag, J. C., Aldigier, J. C., \& Leroux-Robert, C. (1998). Acute renal failure in a marathon runner: role of glomerular bleeding in tubular injury. The American Journal of Medicine, 105, 251-252.

Miyai, T., \& Ogata, M. (1990) Changes in the Concentrations of Urinary Proteins after Physical Exercise. Acta Medica Okayama, 44, 263-266.

Moreira, A., Okano, A.H., Souza, M., Oliveira, P.R., \& Gomes, A.C. (2005) Sistema de cargas seletivas no basquetebol durante um mesociclo de preparação: implicações sobre a velocidade e as diferentes manifestações de força. Revista Brasileira de Ciência e Movimento, 13, 7-15.

Mueller, S.M., Anliker, E., Knechtle, P., Knechtle, B., \& Toigo, M. (2013) Changes in body composition in triathletes during an Ironman race. European Journal of Applied Physiology, 113, 2343-2352.

Mydlík, M., Derzsiová, K., \& Bohus, B. (2012). Renal function abnormalities after marathon run and 16-kilometre long-distance run. Przegl Lek, 69, 1-4.

Mydlík, M., Derzsiová, K., \& Bohus, B. (2009). Changes in renal functional investigation after marathon run, 100- kilometer run and after 24-hour long-term race. Vnitø Lék, 55(S1).

O’Neal, E.K., Wingo, J.E., Richardson, M.T., Leeper, J.D., Neggers, Y.H., \& Bishop, P.A. (2011). Half-Marathon and Full-Marathon Runners' Hydration Practices and Perceptions. Journal of Athletic Training, 46, 581-591.
O’Toole, M.L., Hiller, W.D., Roalstad, M.S., \& Douglas, P.S. (1988). Hemolysis during triathlon races: its relation to race distance. Medicine \& Science in Sports \& Exercise, 20, 272-275.

Poortmans, J. (1984). Exercise and Renal Function. Sports Medicine, $1,125-153$.

Puggina, E.F., Machado, D.R., Borges, G.A., \& Barbanti, V.J. (2011). Changes in Body Composition after Endurance Training and Triathlon Competition. Human Movement, 12, 361-366.

Puggina, E.F., Machado, D.R., Tourinho Filho, H., \& Barbanti, V.J. (2014) Half-ironman induces changes in the kidney function of triathletes. Annals of the Brazilian Academy of Sciences, 86, 429-436.

Reuben, D.B., Wachtel, T.J., Brown, P.C., \& Driscoll, J.L. (1982). Transient Proteinuria in emergency medical admissions. New England Journal of Medicine, 306, 1031-1033.

Robert, W., Kenefick, K., \& Sawka, M.N. (2007). Heat Exhaustion and Dehydration as Causes of Marathon Collapse. Sports Medicine, 37, 378-381.

Roberts, W.O. (2000). A 12-year profile of medical injury and illness for the Twin Cities Marathon. Medicine \& Science in Sports \& Exercise, 32, 1549-1555.

Von Duvillard, S.P., Braun, W.A., Markofski, M., Beneke, R., \& Leithäuser, R. (2004). Fluids and hydration in prolonged endurance performance. Nutrition, 20, 651-656.

\section{Authors' note}

Luiz Guilherme Cruz Gonçalves (luiz.goncalves@usp.br), Rodrigo Leal de Queiroz Thomaz de Aquino (rodrigo.aquino@usp.br) and Enrico Fuini Puggina (enrico@usp.br) are affiliated with the University of São Paulo.

\section{Corresponding author}

Enrico Fuini Puggina

Avenue Bandeirantes, $n^{\circ}$ 3900, 14040-907, Ribeirão Preto, Brazil. Tel: +55 $163315-0342$

E-mail: enrico@usp.br

Manuscript received on October 3, 2014

Manuscript accepted on July 7, 2015

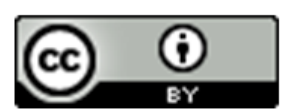

Motriz. The Journal of Physical Education. UNESP. Rio Claro, SP, Brazil - eISSN: 1980-6574 - under a license Creative Commons - Version 3.0 